\title{
Dual Intrinsic and Extrinsic Origins of CGRP- and NPY-Immunoreactive Nerves of Rat Gut and Pancreas
}

\author{
H. C. Su, A. E. Bishop, R. F. Power, Y. Hamada, and J. M. Polak \\ Department of Histochemistry, Royal Postgraduate Medical School, London W12 OHS, UK
}

The origins of nerves containing calcitonin gene-related peptide (CGRP), neuropeptide $Y$ (NPY), and substance $P$ were investigated in the rat stomach, pancreas, and colon, using immunocytochemistry combined with retrograde tracing and surgical and chemical denervation procedures. Compared with nerves containing vasoactive intestinal polypeptide (VIP) and galanin, which have primarily local origins in mammalian gut, CGRP-, NPY-, and substance P-immunoreactlve nerves revealed dual extrinsic and intrinsic origins. Immunocytochemistry combined with retrograde tracing showed that the extrinsic CGRP- and substance P-immunoreactive nerves in the stomach and pancreas originate from bilateral dorsal root ganglia mainly at levels T8-T11, while those of the colon are derived from bilateral ganglia at S1 and, to a lesser extent, L1 and L6. Chemical denervations showed that neurons in these ganglia form a sensory input to the gut, and that those containing CGRP form the largest proportion. The results of combined retrograde tracing and immunocytochemistry indicated that extrinsic NPYimmunoreactive nerves originate from postganglionic sympathetic neurons lying in the coeliac and inferior mesenteric ganglia. These nerves were located mainly around blood vessels in gut and pancreas, showed sensitivity to 6-hydroxydopamine, and thus are likely to be noradrenergic. The present study provides a detailed mapping of the origins of some of the major peptide-containing nerves of the rat gastroenteropancreatic tract, thus providing further information on the anatomy of the enteric innervation.

The existence of a widespread system of peptide-containing nerves is now well established for the gut and pancreas of mammals. Since the first description of substance $P$ in enteric neurons (Nilsson et al., 1975; Pearse and Polak, 1975), more than 10 neuropeptides have been localized to gut nerves (Polak and Bloom, 1979; Furness and Costa, 1980; Schultzberg et al., 1980; Sundler et al., 1980; Bishop et al., 1982) and at least 8 neuropeptides have been found in the pancreatic innervation (Sundler et al., 1978; Larsson, 1979; Bishop et al., 1980; Prinz et al., 1983; Ghatei et al., 1984; Carlei et al., 1985).

Two of the latest neuropeptides to be discovered are calcitonin gene-related peptide (CGRP) and neuropeptide Y (NPY). CGRP is a novel 37 amino acid peptide produced by alternative calcitonin gene expression (Amara et al., 1982; Rosenfeld et al.,

Received June 9, 1986; revised Dec. 23, 1986; accepted Feb. 20, 1987

H.C.S. was supported by an Overseas Research Studentship. The authors thank Miss S. Lock for typing the manuscript.

Correspondence should be addressed to J. M. Polak at the above address.

Copyright (C) 1987 Society for Neuroscience $0270-6474 / 87 / 072674-14 \$ 02.00 / 0$
1983). CGRP has been found in autonomic and motor nerves, as well as in sensory nerves, where it frequently coexists with substance P (Gibson et al., 1984; Wiesenfeld-Hallin et al., 1984; Clague et al., 1985; Fischer et al., 1985; Gibbins et al., 1985; Lee et al., 1985a, b; Lundberg et al., 1985; Rodrigo et al., 1985; Takami et al., 1985; Terenghi et al., 1985; Gulbenkian et al., 1986; Sternini et al., 1986). In the gastrointestinal tract and pancreas, CGRP-immunoreactive nerves have been found to have a wide distribution (Clague et al., 1985; Mulderry et al., 1985; Sternini and Brecha, 1986). Preliminary findings have indicated that CGRP-immunoreactive somata can be visualized in the intestine but not in the stomach of colchicine-treated rats, suggesting that the nature of the CGRP innervation differs along the rat gut (Clague et al., 1985). However, no systematic study has been made of the exact origins of these nerves.

Neuropeptide $Y$ is a 36 amino acid residue peptide (Tatemoto et al., 1982) which has been localized by immunocytochemistry to the central nervous system and to nerves in several peripheral tissues, including the gut and pancreas (Lundberg et al., 1982, 1984a, b; Furness et al., 1983; Sundler et al., 1983; Ekblad et al., 1984a, b; Ferri et al., 1984; Carlei et al., 1985; Lee et al., $1985 \mathrm{c}$ ). It has been suggested that enteric NPY-immunoreactive nerves have a dual extrinsic and intrinsic origin (Sundler et al., 1983; Ferri et al., 1984; Polak and Bloom, 1984; Lee et al., $1985 \mathrm{c}$ ). It has also been reported that NPY immunoreactivity is frequently associated with sympathetic noradrenergic nerves (Lundberg et al., 1982, 1983; Hökfelt et al., 1983; Ekblad et al., 1984c; Ferri et al., 1984; Polak and Bloom, 1984; Lee et al., 1985c; Allen and Bloom, 1986).

In the present study, the distributions and origins of CGRP-, NPY-, and substance P-immunoreactive nerves were determined in the stomach, pancreas, and colon of the rat and compared with those of 2 other major gut neuropeptides, vasoactive intestinal polypeptide (VIP) and galanin, which have primarily local origins.

\section{Materials and Methods}

Animals

Adult rats (Wistar; 150-250 gm) of both sexes were used in all experiments. Animals undergoing surgery were anesthetized with Diazepam (Roche Products; $10 \mathrm{mg} / \mathrm{kg}$, i.p.) and fenthamylcitrate/fluanison (Hypnorm; Janssen Pharmaceuticals; $5 \mathrm{mg} / \mathrm{kg}$, i.m.).

\section{Colchicine injection}

Colchicine was used to block granule transport in axons in order to increase the peptide content in the neuronal cell body. Colchicine (5 $\mathrm{mg} / \mathrm{kg}$; Sigma, UK) dissolved in saline was injected intraperitoneally $(n=5)$. The rats were killed $48 \mathrm{hr}$ later with an overdose of sodium 


\begin{tabular}{llllllll} 
& Region & & Coupling & & Dilution & & \multicolumn{2}{l}{$\begin{array}{l}\text { Quenching } \\
\text { (nmol/ } \\
\text { specificity }\end{array}$} & Carrier & $\begin{array}{l}\text { Cagent } \\
\text { antisera to }\end{array}$ & IF & PAP & \\
\hline CGRP (synthetic) & C-term & BSA & BDB & $1 / 200$ & $1 / 2000$ & 0.01 \\
NPY (natural porcine) & Whole & KLH & BDB & $1 / 400$ & $1 / 2000$ & 0.1 \\
Substance P (synthetic) & C-term & BSA & Glut & $1 / 500$ & $1 / 5000$ & 1.0 \\
VIP (natural porcine) & Whole & KLH & BDB & $1 / 2000$ & $1 / 10,000$ & 0.1 \\
Galanin (natural porcine) & Whole & - & - & $1 / 1000$ & $1 / 5000$ & 0.1 \\
\hline
\end{tabular}

Key: BDB, bis-diazobenzidine; BSA, bovine serum albumin; Glut, glutaraldehyde; KLH, keyhole limpet hemocyanin; IF indirect immunofluorescence method; PAP, peroxidase-antiperoxidase method; Whole, immunostaining is quenched only by whole antigen. C-term, immunostaining is quenched by C-terminal fragment of the antigen.

pentobarbitone (Euthatal; May and Baker). The stomach, pancreas, and colon were dissected out and processed for immunohistochemistry.

\section{Capsaicin treatment}

In order to destroy primary sensory afferents, capsaicin was applied. Rats $(n=10)$ were treated with capsaicin (8-methyl- $N$-vanillyl 5-nonenamide; Fluka $A G)$ cmulsificd in vehicle $(10 \mathrm{mg} / \mathrm{ml})$ containing $10 \%$ ( $\mathrm{vol} / \mathrm{vol})$ ethanol, $10 \%(\mathrm{vol} / \mathrm{vol})$ Tween 80 , and $80 \%(\mathrm{vol} / \mathrm{vol})$ isotonic saline. Neonatal rats received $50 \mathrm{mg} / \mathrm{kg}$ of capsaicin intraperitoneally on days 2 and 3 of postnatal life under light ether anesthesia. Control animals $(n=10)$ were injected with vehicle alone. The stomach, pancreas, and colon were collected from rats when adult (2-3 months old).

\section{Surgical denervation}

Stomach and pancreas. Upper abdominal sympathectomy was performed in 5 rats. The procedure was essentially that of Holmes (1953). The coeliac ganglion and plexus and the superior mesenteric ganglion were carefully stripped away without undue hemorrhage. The presence of ganglia and nerve plexus was verified on microscopic sections.

Bilateral subdiaphragmatic vagotomy (Shay et al., 1949) was carried out in a separate group of rats $(n=5)$.

All the animals were allowed to recover for $8 \mathrm{~d}$ postoperatively, after which time the stomach and pancreas were collected for immunocytochemistry.

Distal colon. Inferior mesenteric ganglionectomy and bilateral section of the pelvic nerve were performed in 5 rats. The inferior mesenteric ganglia and nerves around the lower part of the abdominal aorta and the inferior mesenteric artery were removed and the pelvic nerves sectioned proximal to the pelvic ganglia.

\section{6-Hydroxydopamine treatment}

A separate group of rats $(n=5)$ was injected intraperitoneally with a freshly prepared solution of 6-hydroxydopamine hydrobromide (6OHDA; Sigma) in saline with $0.1 \%$ ascorbic acid $(100 \mathrm{mg} / \mathrm{kg}$ body weight) at 1,7 , and $8 \mathrm{~d}$, and control animals $(n=5)$ were injected with saline alone at the same time. On day 9 , animals were killed and the stomach, pancreas, and colon werc removed for immunocytochemistry.

\section{Combined immunocytochemistry and retrograde tracing}

Retrograde tracing. The possible extrinsic origins of CGRP-, NPY-, and substance P-immunoreactive nerves in the rat stomach, pancreas, and distal colon were examined by combined immunocytochemistry and retrograde tracing, using the fluorescent dye True blue [trans-1,2-bis(5amidino-2-bensofluranyl) ethylene $2 \mathrm{HCl}$ ] (Sigma) (Sawchenko and Swanson, 1981; Sharkey et al., 1983). In 3 groups of 4 rats each, the stomach, pancreas, or distal colon was exposed in fully anesthetized rats and a $5-10 \mu$ l suspension of True blue in distilled water $(5 \% \mathrm{wt} / \mathrm{vol})$ was injected into the duodenal and splenic lobes of the pancreas and the anterior and posterior walls of the stomach and distal colon, respectively, at 8-12 loci with a Hamilton microsyringe. In order to prevent tracer leakage into the peritoneal cavity, leading to false-positive labeling, the organs to be investigated were gently lifted out of the abdominal cavity and placed on Parafilm during the course of the injection. After each injection, the needle was left in place for $1 \mathrm{~min}$. Before replacement into the abdomen the organs were thoroughly swabbed and the injection sites inspected; furthermore, a barrier formed by a plastic wound spray (Nobecutane; Astra Pharmaceuticals, Watford, UK) was applied to the surfaces of dye-injected organs (Fox and Powley, 1986).

To ensure that the retrograde labeling was specific for each injected organ and did not reflect uptake of circulating dye from the bloodstream, $10 \mu$ of True blue was injected into the portal vein of 2 control rats, as this vein drains most of the blood from the digestive organs.

Tissue processing and quantification. Seven days after injection, the rats were anesthetized and perfused with $150-200 \mathrm{ml}$ of $0.1 \mathrm{M}$ phosphate-buffered $0.015 \mathrm{M}$ saline (PBS, pII 7.2), followed by $300-400 \mathrm{ml}$ of ice-cold paraformaldehyde solution ( $4 \% \mathrm{wt} / \mathrm{vol}$ in PBS). The dorsal root ganglia (from T4 to S2), and nodose ganglia, pelvic ganglia, coeliac ganglia, inferior mesenteric ganglia, spinal cord, and brain stem were dissected out and placed in an additional solution of paraformaldehyde for $1 \mathrm{hr}$, then washed extensively with PBS containing 15\% (wt/vol) sucrose at $4^{\circ} \mathrm{C}$ for at least $24 \mathrm{hr}$. Alternate $10-\mu \mathrm{m}$-thick cryostat sections were processed for immunofluorescence staining with antisera to CGRP, NPY, and substance $\mathbf{P}$ (Table 1). Sections were examined with a fluorescent microscope (Olympus $\mathrm{AH}-2$ ) equipped for epi-illumination with filters having excitation wavelengths of 340-380 nm (True blue) and 450-490 nm (fluorescein). Localization of CGRP, NPY, or substance $P$ immunoreactivity in True blue-labeled cell bodies was verified by changing filter systems without altering the focal plane. All True blue-labeled cells from alternate sections of each dorsal root ganglion were counted. The number of labeled cells in each ganglion was expressed as a percentage of the total labeled cells. The proportion of True blue-labeled cells that contained CGRP, NPY, or substance P immunoreactivity was also recorded.

\section{Immunocytochemistry}

Tissues other than those in the retrograde tracing experiments were fixed with either $0.4 \%(\mathrm{wt} / \mathrm{vol}) p$-benzoquinone (Köch-Light) or $4 \%$ paraformaldehyde. Tissues were washed thoroughly in several changes of PBS containing sucrose (15\% wt/vol) and sodium azide $(0.01 \% \mathrm{wt} /$ vol) for at least $24 \mathrm{hr}$ prior to sectioning. Cryostat sections $(10 \mu \mathrm{m})$ were cut and mounted on poly-L-lysine-coated slides (Huang et al., 1983). The method of immunostaining employed was either indirect immunofluorescence (Coons et al., 1955) or the peroxidase-antiperoxidase technique (Sternberger et al., 1970). Antisera were raised in rabbits; their characteristics are summarized in Table 1.

\section{Results}

Normal distribution

Neuronal elements with CGRP, NPY, substance P, VIP, and galanin immunoreactivity were observed throughout the wall of the rat stomach and colon, and were also found in the pancreas. Briefly, CGRP-immunoreactive fibers were observed in the mucosa, submucosa, and muscle layers of the stomach (Fig. 1) and colon (Fig. 2) where they showed a frequent association with blood vessels. No CGRP immunoreactivity could be detected in neuronal cell bodies of either of the 2 main ganglionated plexuses of the stomach, even after treatment with colchicine. However, this treatment did allow demonstration of a few CGRP- 

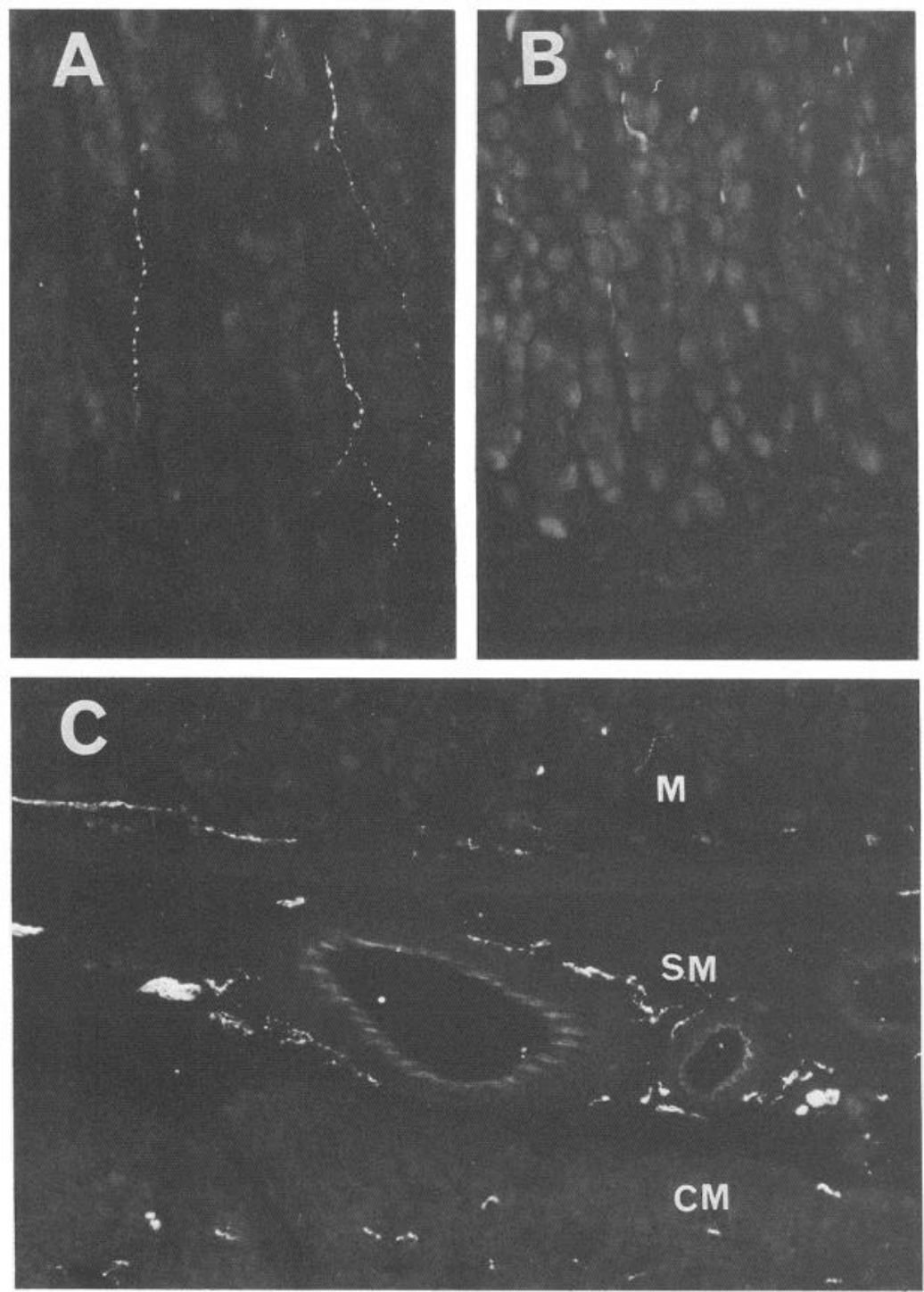

Figure 1. Distribution of CGRP immunoreactivity in nerves of the rat stomach. $A$, Scattered CGRP nerves in the lamina propria of fundic mucosa from a normal rat. $B$, An area similar to that shown in $A$ taken from a rat treated neonatally with capsaicin. No CGRP-immunoreactive fibers can be seen. A few autofluorescent blood vessels can be discerned towards the upper part of the mucosa. $C$, The mucosa $(M)$, submucosa $(S M)$, and inner edge of the circular muscle $(C M)$ of normal rat stomach with numerous scattered CGRP-immunoreactive fibers. Many fibers show a close association with submucosal blood vessels. $D$, Muscularis propria of normal rat stomach, showing a significant level of CGRP innervation. The fibers are seen mainly as finely intertwined bundles. $A-D$, $\times 225$.

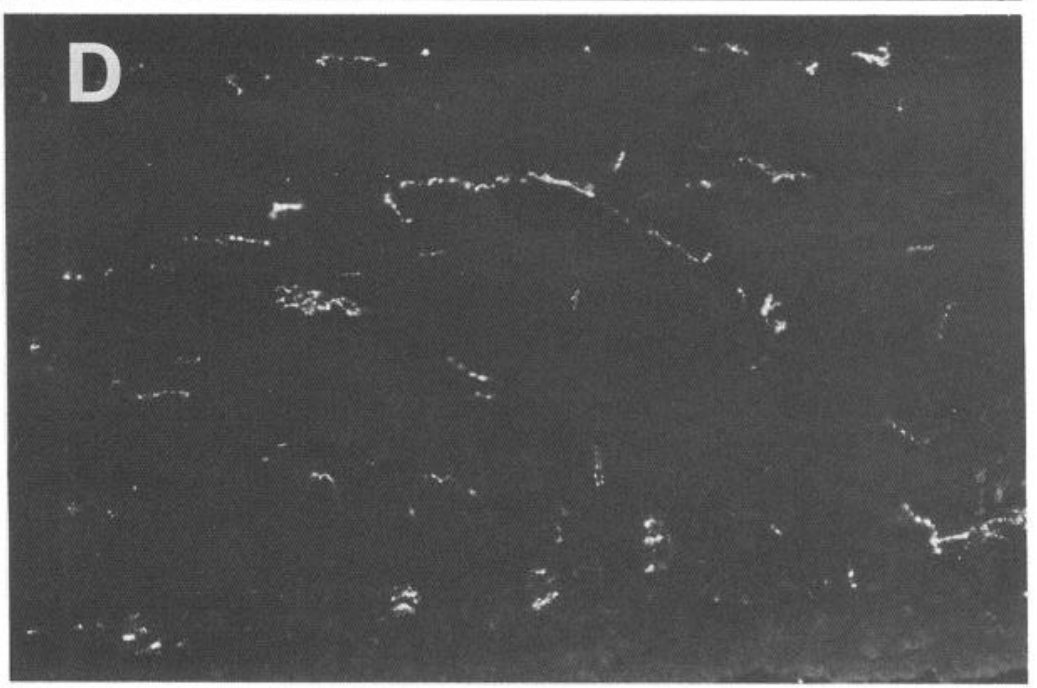

immunoreactive ganglion cells in both the myenteric (Fig. $2 B$ ) and submucous plexuses of the colon. A similar distribution of both NPY - (Fig. 3) and substance P-immunoreactive fibers was identified in these 2 organs, except for the muscle layers, where substance P nerves were more abundant. NPY immunoreactivity could be seen in moderate numbers of ganglion cells of both plexuses in the stomach and colon. The number and intensity of immunostaining of these cells increased following colchicine 

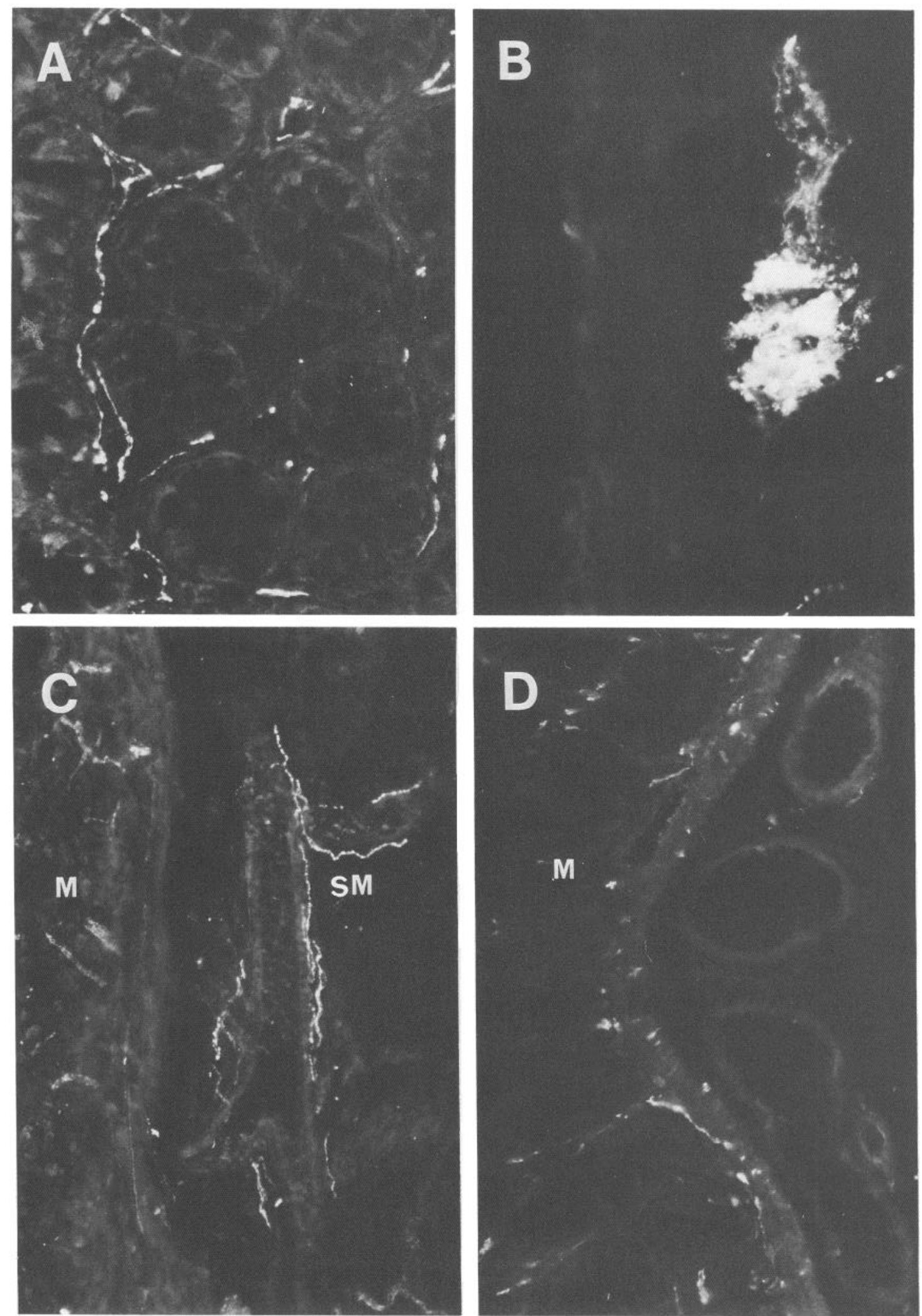

Figure 2. Distribution of CGRP immunoreactivity in nerves of the rat colon. A, CGRP-immunoreactive fibers showing close association with the surface and glandular epthelium of colonic mucosa. $\times 310 . B$, Ganglion cells of the myenteric plexus of colon taken from a rat treated with colchicine. CGRP immunoreactivity can be seen in the cells. The paucity of immunoreactive fibers in surrounding muscle is an effect of the chemical treatment. $\times 600$. C, CGRP-immunoreactive fibers in the mucosa $(M)$ and submucosa $(S M)$ of normal rat colon. The fibers show a close association with the submucosal blood vessels. $\times 225$. $D$, An area similar to that shown in $C$, taken from a rat neonatally treated with capsaicin. Fibers can be discerned in the mucosa $(M)$ and muscularis mucosae but no nerves are present around blood vessels. $\times 225$. Same fixation and immunostaining techniques as in Figure 1. 

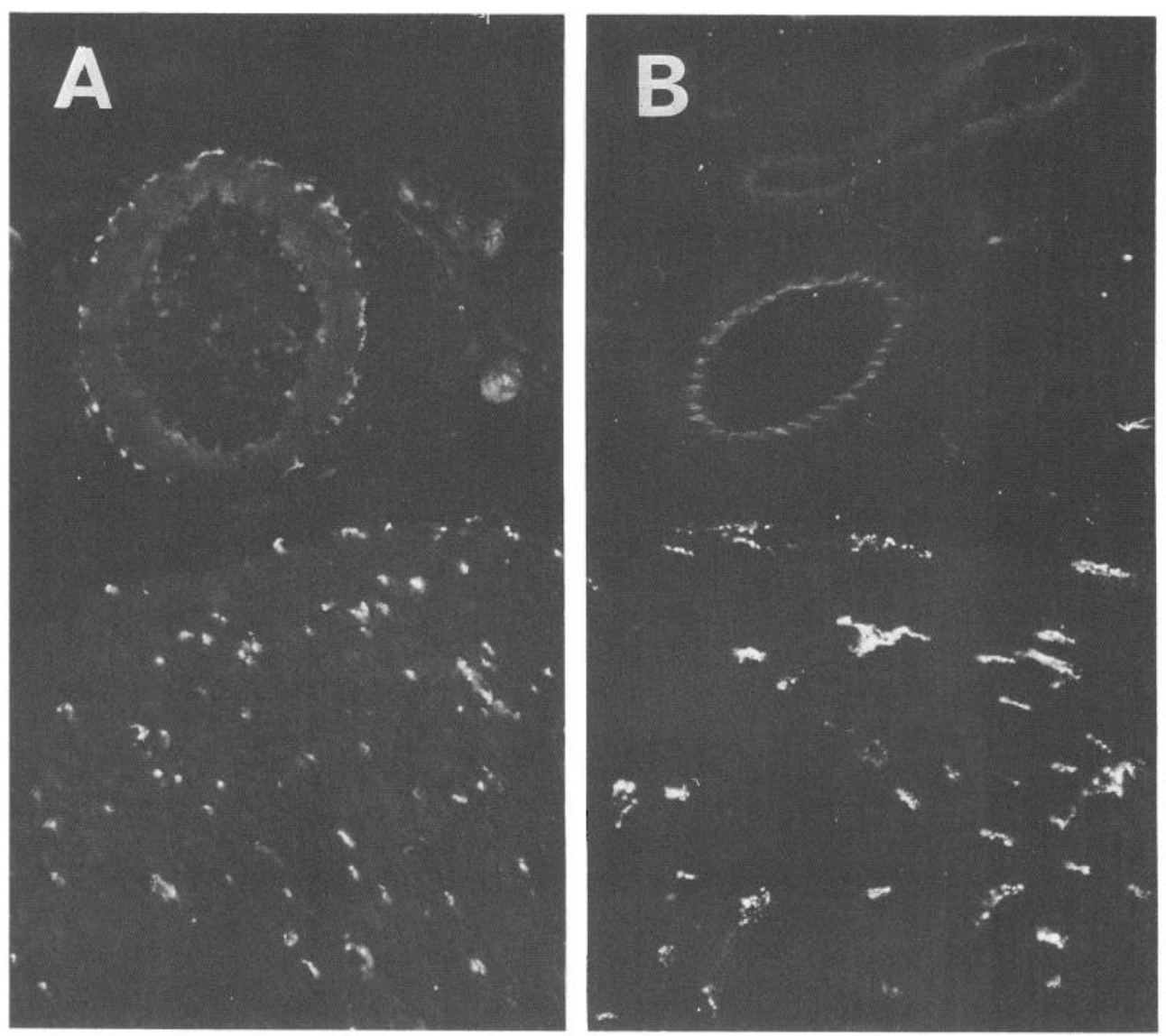

Figure 3. Distribution of NPY immunoreactivity in nerves of the rat stomach. $A$, Inner edge of the circular muscle and the submucosa of normal rat stomach containing numerous NPYimmunoreactive fibers. $\times 225 . B$, An area similar to that shown in $A$ taken from a rat treated with 6-OHDA. NPYimmunoreactive fibers are missing from around blood vessels, but those in the muscle remain unaffected. $\times 225$. $C$, Ganglion cells of the myenteric plexus of stomach taken from a rat treated with colchicine. NPY immunoreactivity can be seen in some of the cells. $\times 500$. Cryostat sections of benzoquinone solution-fixed tissue immunostained by $(A, B)$ the technique of indirect immunofluorescence and $(C)$ the peroxidase-antiperoxidase technique.

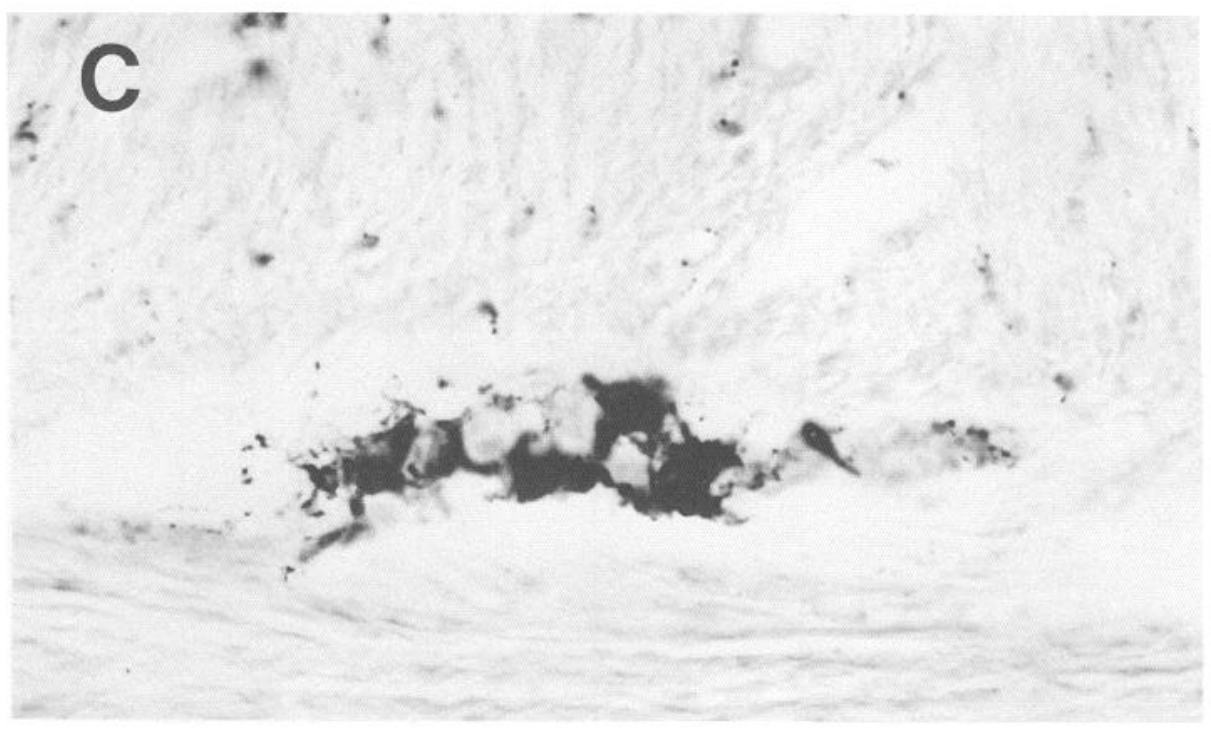

administration (Fig. 3C). Similar results were obtained for substance P. VIP and galanin immunoreactivities were widespread in nerves of all layers of both stomach and colon, and could be demonstrated frequently in ganglion cells, particularly of the submucous plexus, both with and without colchicine treatment.

In the pancreas, CGRP immunoreactivity was localized to nerve fibers that ran in the inter- and intralobular spaces. They were often found in or around islets and near blood vessels (Fig. 4). As previously reported (Sternini and Brecha, 1986), CGRP immunoreactivity was also found in single or clustered endo- crine cells (Fig. 4A). No immunoreactive ganglion cells could be visualized even after colchicine treatment. NPY-containing fibers showed a similar distribution in the exocrine parenchyma and around vascular structures, but were not seen in association with endocrine cells. No immunoreactive ganglion cells could be detected even after colchiciri treatment. Substance P, VIP, and galanin immunoreactivities all showed fairly similar widespread distributions in the pancreas, with VIP-immunoreactive fibers being most abundant in and most frequently associated with the islets. Ganglion cells immunoreactive for VIP were 

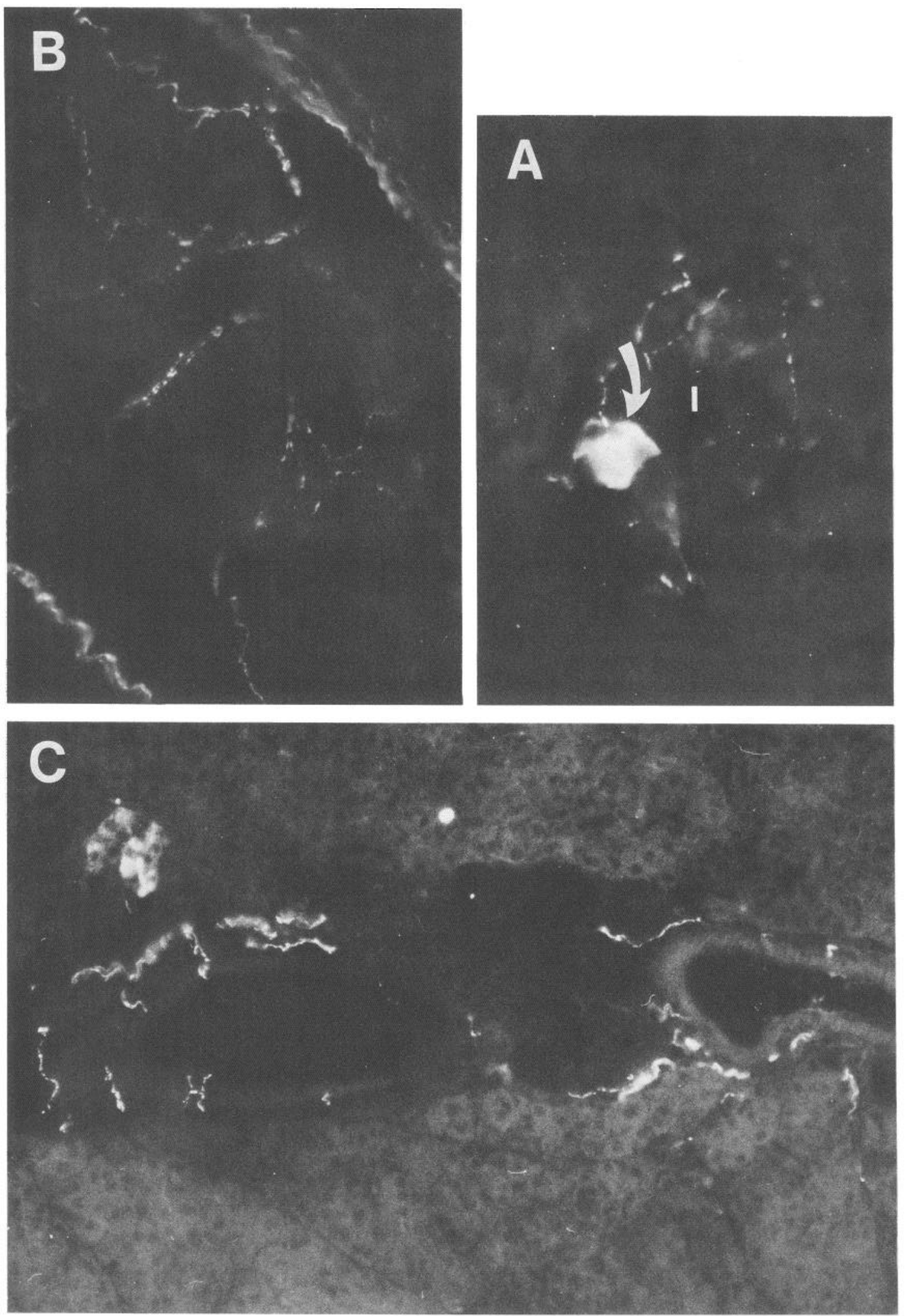

Figure 4. Distribution of CGRP immunoreactivity in the rat pancreas. $A$, An islet of Langerhans $(I)$ with associated CGRP-immunoreactive fibers. The peptide was also immunostained in a few of the endocrine cells (arrow). $\times 300$. $B$, Network of CGRP nerves around the longitudinally sectioned wall of a blood vessel. $\times 450$. $C$, CGRP-immunoreactive fibers around blood vessels in the interlobular spaces of the rat pancreas. Some immunoreactive endocrine cells can also be seen. $\times 130$. 
Table 2. Stomach

\begin{tabular}{lllll} 
& \multicolumn{5}{c}{ Experimental procedures } \\
\cline { 2 - 5 } Neuropeptides & treatment & Vagotomy & $\begin{array}{l}\text { Sympa- } \\
\text { thectomy }\end{array}$ & $\begin{array}{l}\text { 6-OHDA } \\
\text { treatment }\end{array}$ \\
\hline CGRP & $\downarrow$ & $\leftrightarrow$ & $\downarrow \downarrow$ & $\leftrightarrow$ \\
NPY & $\leftrightarrow$ & $\leftrightarrow$ & $\downarrow$ & $\downarrow$ \\
Substance P & $\downarrow$ & $\leftrightarrow$ & $\downarrow$ & $\leftrightarrow$ \\
VIP & $\leftrightarrow$ & $\leftrightarrow$ & $\leftrightarrow$ & $\leftrightarrow$ \\
Galanin & $\leftrightarrow$ & $\leftrightarrow$ & $\leftrightarrow$ & $\leftrightarrow$ \\
\hline
\end{tabular}

Key: $\downarrow$, Remarkable decrease; $\rfloor$, decrease; $\bullet$, no noticeable change from control.

seen with or without colchicine administration, but substance $\mathrm{P}$ and galanin were found only rarely in cell bodies after colchicine.

\section{Chemical and surgical denervations}

The effects of chemical and surgical denervations on CGRP-, NPY-, substance P-, VIP-, and galinin-immunoreactive nerves in the rat stomach, pancreas, and colon are summarized in Tables 2-4.

Neonatal capsaicin administration. Following neonatal capsaicin administration, CGRP-immunoreactive fibers almost completely disappeared from the stomach (Fig. 1, $A, B$ ) and pancreas. In contrast, only a moderate depletion of CGRPimmunoreactive nerve fibers was seen in the colon, this being most evident around blood vessels (Fig. 2, $C, D$ ). In the stomach and colon, capsaicin treatment resulted in a decrease in the number of substance P-immunoreactive fibers in the mucosa and submucosa and in a complete loss of perivascular nerves, whereas no changes in the number of nerves were noticed in the muscle layers. In the pancreas, the population of substance $P$-immunoreactive nerves was reduced substantially and the perivascular staining completely abolished. There were no apparent changes in NPY-, VIP-, and galanin-immunoreactive nerves after capsaicin treatment.

Surgical denervations. All of the surgical denervations, except vagotomy, had the effect of reducing both CGRP- and substance P-immunoreactive nerve fibers, as after capsaicin treatment. Bilateral subdiaphragmatic vagotomy caused no obvious alterations. There was a loss of NPY-immunoreactive fibers from around blood vessels of the stomach and pancreas of the upper abdominal sympathectomized rats and of the denervated colon. None of the surgical denervation procedures had any apparent influence on either VIP- or galanin-immunoreactive nerves.

6-OHDA treatment. After 6-OHDA treatment, NPY-im-

Table 3. Pancreas

\begin{tabular}{lllll} 
& \multicolumn{5}{c}{ Experimental procedures } \\
\cline { 2 - 5 } Neuropeptides & $\begin{array}{l}\text { Capsaicin } \\
\text { treatment }\end{array}$ & Vagotomy & $\begin{array}{l}\text { Sympa- } \\
\text { thectomy }\end{array}$ & $\begin{array}{l}\text { 6-OHDA } \\
\text { treatment }\end{array}$ \\
\hline CGRP & $\Downarrow$ & $\leftrightarrow$ & $\downarrow$ & $\leftrightarrow$ \\
NPY & $\leftrightarrow$ & $\leftrightarrow$ & $\downarrow$ & $\downarrow$ \\
Substance P & $\Downarrow$ & $\leftrightarrow$ & $\downarrow$ & $\leftrightarrow$ \\
VIP & $\leftrightarrow$ & $\leftrightarrow$ & $\leftrightarrow$ & $\leftrightarrow$ \\
Galanin & $\leftrightarrow$ & $\leftrightarrow$ & $\leftrightarrow$ & $\leftrightarrow$ \\
\hline
\end{tabular}

Key: $\downarrow$, Remarkable decrease; $\downarrow$, decrease; $\leftrightarrow$, no noticeable change from control
Table 4. Colon

\begin{tabular}{|c|c|c|c|}
\hline \multirow[b]{2}{*}{ Neuropeptides } & \multicolumn{3}{|c|}{ Experimental procedures } \\
\hline & $\begin{array}{l}\text { Capsaicin } \\
\text { treatment }\end{array}$ & $\begin{array}{l}\text { Surgical } \\
\text { denervation }\end{array}$ & $\begin{array}{l}\text { 6-OHDA } \\
\text { treatment }\end{array}$ \\
\hline CGRP & $\downarrow$ & $\downarrow$ & $\leftrightarrow$ \\
\hline NPY & $\leftrightarrow$ & $\downarrow$ & $\downarrow$ \\
\hline Substance $\mathbf{P}$ & $\downarrow$ & $\downarrow$ & $\leftrightarrow$ \\
\hline VIP & $\leftrightarrow$ & $\leftrightarrow$ & $\leftrightarrow$ \\
\hline Galanin & $\leftrightarrow$ & $\leftrightarrow$ & $\leftrightarrow$ \\
\hline
\end{tabular}

Key: $\downarrow$, Remarkable decrease; $\downarrow$, decrease; $\rightarrow$, no noticeable change from control

munoreactive nerves in the stomach (Fig. 3, $A, B$ ), pancreas, and colon disappeared from around blood vessels and were reduced in number in the myenteric plexus. No changes in CGRP, substance $\mathbf{P}$, VIP, or galanin immunoreactivities were observed.

\section{Immunocytochemistry combined with retrograde tracing}

Retrograde tracing experiments showed that the location of True bluc-labeled cells was dependent on the organs into which the dye was injected. Injection into stomach resulted in the labeling of cells in bilateral T5-L1 dorsal root ganglia, with most (about $80 \%$ ) of the labeled cells lying in T8-T11 (Fig. 5). True bluelabeled cells were also seen bilaterally in the nodose ganglia, dorsal motor nucleus of the vagus (Fig. 6), and celiac ganglia. Occasionally True blue-labeled cells were found in the nucleus ambiguus. Injection of the tracer into the pancreas led to a similar distribution of labeled cells (Fig. 5), except that there were fewer labeled cells than after the injection of the dye into the stomach. After injection into the distal colon, retrogradely labeled cells were seen in dorsal root ganglia on both sides in 2 groups of ganglia, L6-S1 and T13-L1. The cells were mostly in ganglia at $\mathrm{S} 1$ and, to a lesser extent, at $\mathrm{L} 1$ and $\mathrm{L} 6$ levels (Fig. 5). Labeled cells were also found in the inferior mesenteric ganglia and intermediolateral cell column of the lumbosacral spinal cord, but not in the nodose or pelvic ganglia. Labeled cells in the dorsal root ganglia appeared to be of small $(<20 \mu \mathrm{m})$ and medium (20-40 $\mu \mathrm{m})$ size.

Injection of True blue into the portal vein, a control for nonspecific uptake of dye by the circulation, did not produce the labeling pattern observed after injection of the stomach, pancreas, and colon. Instead, very weakly labeled cells were found in all dorsal root ganglia.

Combined immunocytochemistry with retrograde tracing demonstrated that the majority (about $95 \%$ ) of True blue-labeled cells in dorsal root ganglia that were identified by injection of the tracer into the stomach, pancreas, or descending colon contained CGRP immunoreactivity (Fig. 7). In contrast, only about $50 \%$ of labeled cells in dorsal root ganglia following injection into the stomach or descending colon, and about $20 \%$ after injection into the pancreas, contained substance $P$ immunoreactivity (Fig. 8).

In the nodose ganglia, only a few True blue-labeled cells contained CGRP immunoreactivity, but no True blue and substance P colocalization was seen. No CGRP- or substance $\mathrm{P}$-immunoreactive cell bodies were stained in the dorsal motor nucleus of the vagus, celiac ganglia, inferior mesenteric ganglia, or intermediolateral cell columns of the lumbosacral spinal cord.

Nearly $50 \%$ of True blue-labeled cells in celiac ganglia (Fig. 9) and inferior mesenteric ganglia contained NPY immuno- 
reactivity. No NPY-immunoreactive cell bodies were found in the dorsal root ganglia, nodose ganglia, or dorsal motor nucleus of the vagus.

\section{Discussion}

The results of this investigation, together with those of previous studies, show that the stomach, pancreas, and colon of the rat are rich in nerves containing CGRP (Clague et al., 1985; Mulderry et al., 1985; Sternini and Brecha, 1986), NPY (Sundlcr ct al., 1983; Ekblad et al., 1984b; Ferri et al., 1984; Carlei et al., 1985; Lee et al., 1985c), substance P (Schultzberg et al., 1980; Sundler et al., 1980; Jodal and Lundgren, 1983; Minagawa et al., 1984), VIP (Bryant et al., 1976; Larsson et al., 1976; Bishop et al., 1980; Schultzberg et al., 1980; Jodal and Lundgren, 1983; Bishop et al., 1984; Ekblad et al., 1984a; Yiangou et al., 1985) and galanin (Ekblad et al., 1985; Melander et al., 1985; Bishop et al., 1986).

In the present study, the distributions and origins of each type of peptide-containing nerve were determined. VIP- and galaninimmunoreactive nerve fibers were found to arise mainly from intrinsic sources in the rat gut and pancreas, as has been reported previously (Larsson et al., 1976; Jessen et al., 1980; Sundler et al., 1980; Ekblad et al., 1985; Melander et al., 1985; Bishop et al., 1986). VIP- and galanin-containing nerve cell bodies could be identified easily in both organs without the use of colchicine, and the finding that surgical denervations did not result in any changes in their population indicates that they have an almost entirely intrinsic origin.

Although local NPY- and substance P-immunoreactive neuronal cell bodies were observed after colchicine treatment in areas of gut and pancreas, surgical denervations led to the partial abolishment of nerve fibers containing the 2 peptides, particularly from around blood vessels, thereby supporting the contention that these nerve fibers have dual origins from extrinsic and intrinsic neurons (Furness et al., 1982; Sundler et al., 1983; Ferri et al., 1984; Minagawa et al., 1984; Polak and Bloom, 1984; Lee et al., 1985c).

Compared to nerves containing the other 4 neuropeptides, which showed similar results along the length of the gut, the CGRP-immunoreactive nerves differed in their response to surgical and chemical manipulations. In the stomach and pancreas, no local CGRP-immunoreactive cell bodies were seen, even after colchicine treatment. Upper abdominal sympathectomy removed almost all CGRP-immunoreactive nerve fibers. Thus, the CGRP-immunoreactive nerve fibers of the rat stomach and pancreas are extrinsic, but those of the colon, like those containing substance $P$ and NPY, have dual origins, as local cell bodies were found and surgical denervation caused only a partial loss of CGRP-containing fibers.

Using retrograde tracing combined with immunocytochemistry, it was possible to establish the exact origins of those peptide-containing fibers whose cell bodies lay outside the gut and pancreas. The 2 peptides, CGRP and substance $P$, have been found, by both light and electron microscopy, to coexist in certain neurons (Wiesenfeld-Hallin et al., 1984; Fischer et al., 1985; Gibbins et al., 1985; Gibson et al., 1985; Lee et al., 1985a, b; Lundberg et al., 1985; Terenghi et al., 1985; Gulbenkian et al., 1986; Sternini et al., 1986) and our results showed that, in the rat stomach and pancreas, these nerves have similar distributions and share the same extrinsic origins. The finding that the gastropancreatic substance $P$ innervation of the rat arises from
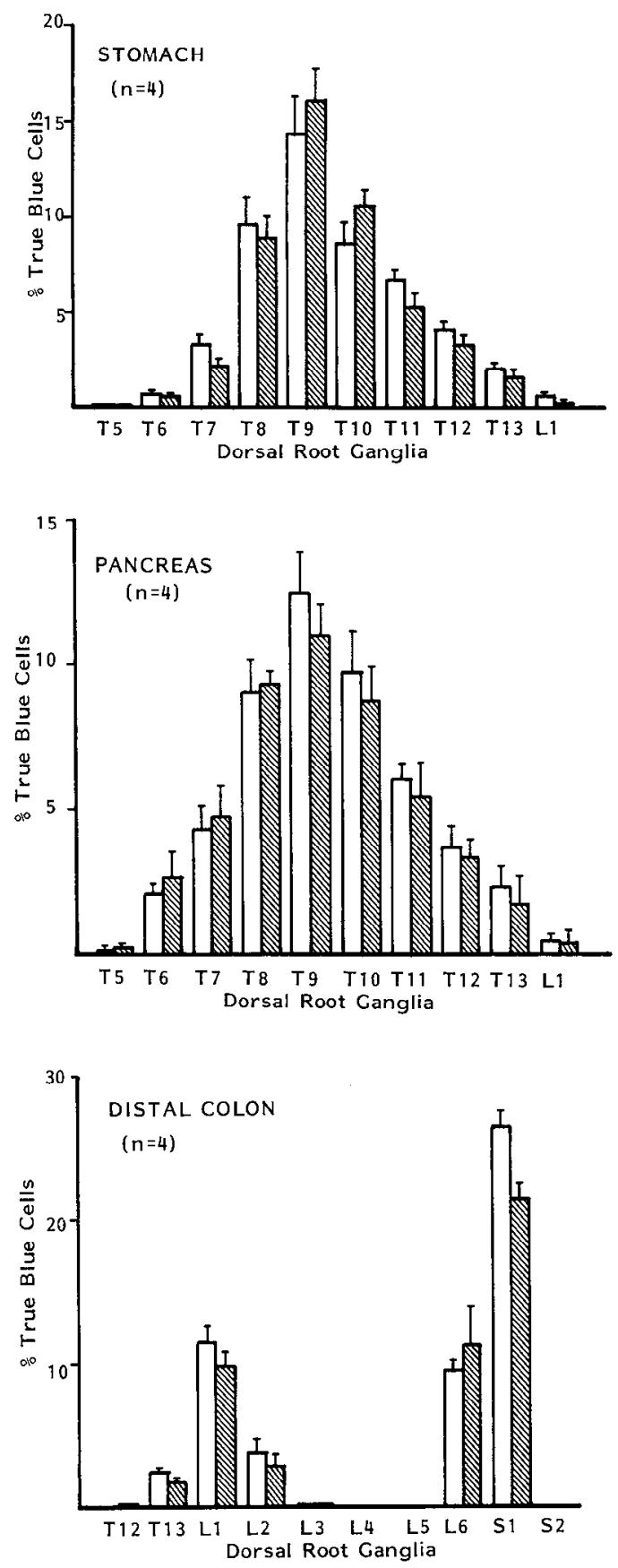

Figure 5. Distribution of retrogradely labeled neuronal cell bodies in bilateral dorsal root ganglia (T5-S1) following injection of True blue into the stomach, pancreas, and colon. The number of labeled cells counted in each ganglion is expressed as a percentage of the total counted at all levels of the spinal cord for each injection site. Colurnns and bars represent means \pm SEM.

bilateral dorsal root ganglia has been reported previously (Sharkey et al., 1984), but we were able to reveal, in addition, that nearly all of the retrogradely labeled cells in these ganglia contain CGRP immunoreactivity. The dorsal root ganglion origin of the CGRP-immunoreactive fibers and the finding that they were abolished by capsaicin treatment indicates that these nerves are 
Figure 6. True blue-labeled cells of the dorsal motor nucleus of vagus following injection of the dye into the wall of the rat stomach. $\times 500$.

Figure 7. A, Section from a rat T9 dorsal root ganglion showing True blue fluorescence after injection of the dye into the stomach. $B$, The same field viewed for fluorescein fluorescence showing cells immunostained for CGRP. $\times 225$. Arrows indicate neuronal cell bodies retrogradely labeled with True blue and displaying CGRP immunoreactivity. Cryostat section of paraformaldehyde-fixed tissue immunostained by indirect fluorescence technique.
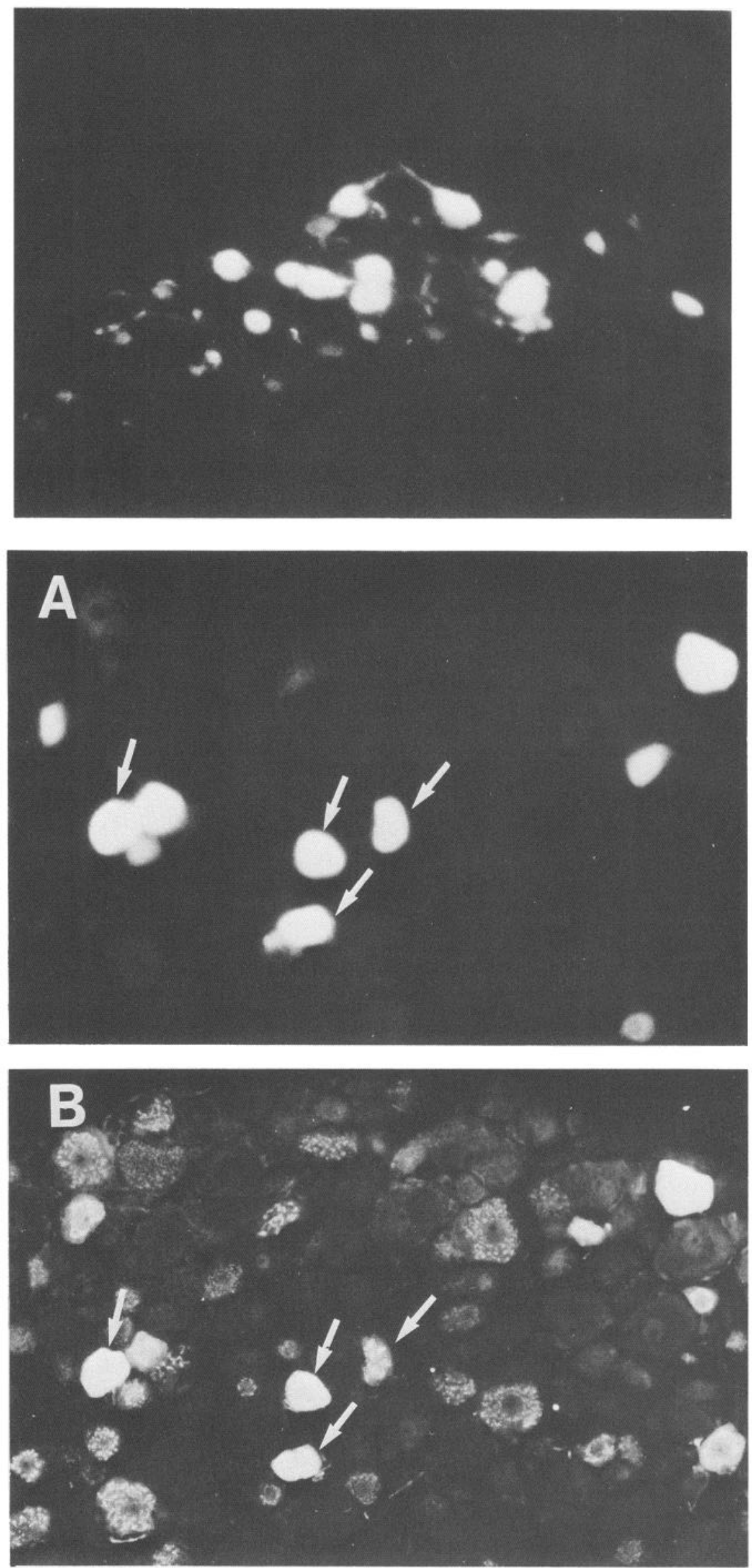

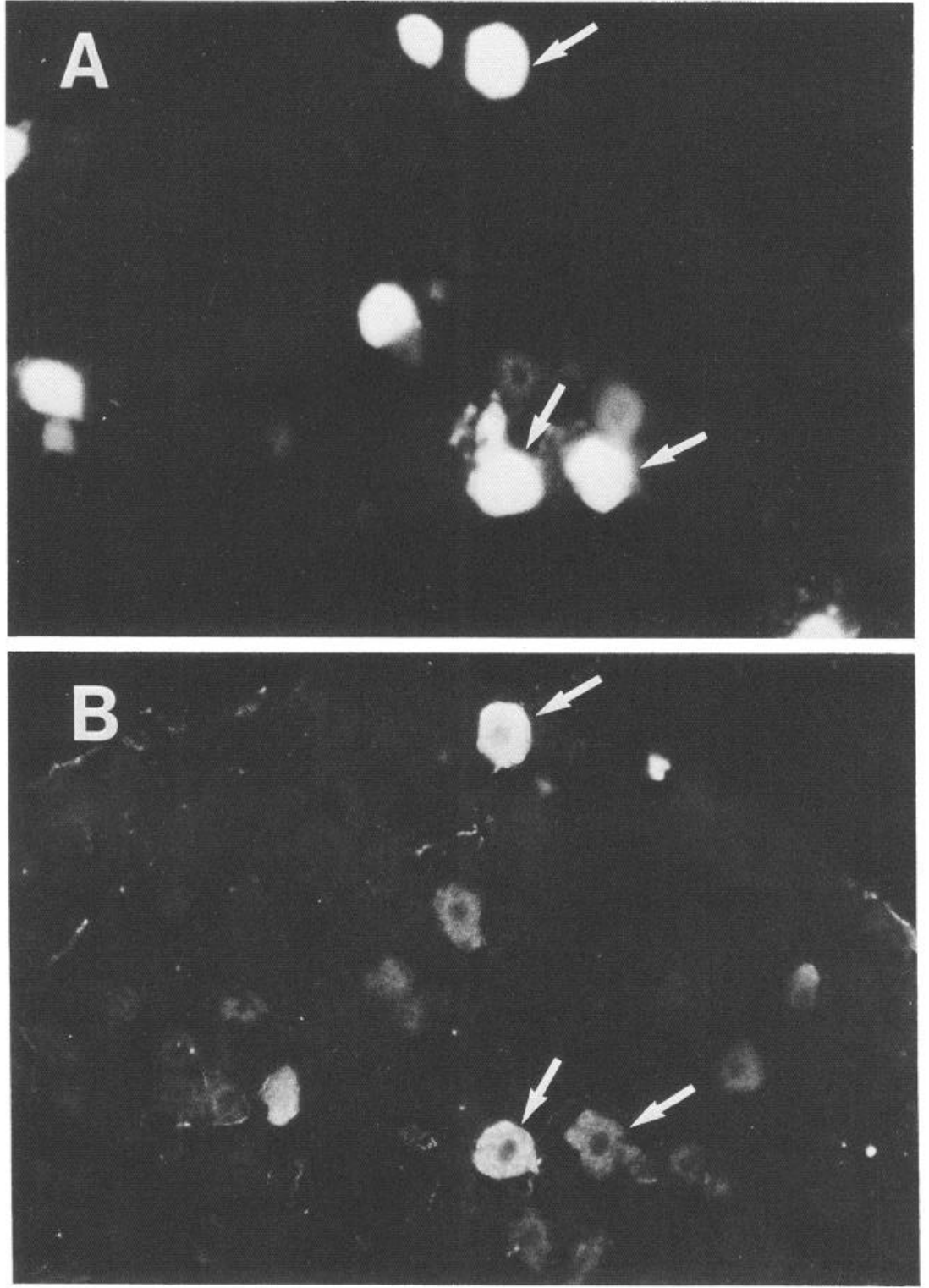

Figure 8. A, Section from a rat S1 dorsal root ganglion showing True blue fluorescence after injection of the dye into the distal colon. $B$, The same field viewed for fluorescein fluorescence showing cells immunostained for substance P. $\times 225$. Arrows indicate neuronal cell bodies retrogradely labeled with True blue and displaying substance P immunoreactivity. Same fixation and immunostaining as in Figure 7 . visceral afferents forming a major component of the sensory innervation of the rat foregut. Those substance P-containing nerves that share their extrinsic origins and also respond to capsaicin administration appear to form a lesser proportion of the sensory innervation. In fact, it has been suggested previously that extrinsic sensory substance $\mathrm{P}$ nerves form only a minor population in the gut and are confined to a perivascular location (Holzer et al., 1980; Furness et al, 1982). An extrinsic sensory nature would explain why the CGRP innervation of the stomach and pancreas is not altered by vagotomy or 6-OHDA treatment. The loss of virtually all CGRP-immunoreactive and some substance P-immunoreactive fibers after upper abdominal sympathectomy is a result of the fact that afferent fibers from the dorsal root ganglia accompany the sympathetic nerves reaching the stomach and pancreas.

In the stomach, CGRP-immunoreactive nerve fibers were associated frequently with blood vessels and smooth muscles. They may participate in the regulation of blood flow, gastric muscle tone (Brain et al., 1984; Feher et al., 1986; Maton et al., 1986), and gastric acid release (Hughes et al., 1984; Tache et al., 1984a, b; Kraenzlin et al., 1985). Since nearly all CGRPimmunoreactive nerve fibers in the stomach originate from the dorsal root ganglia, these functions could be mediated by axonal reflexes. Peptides in visceral afferents are known to travel mainly towards the periphery (Lundberg et al., 1980), and such a reflex mechanism has been proposed for substance P nerves (Lundberg et al., 1985). CGRP-immunoreactive nerves of the exocrine and endocrine pancreas may influence the activity of both organ components. The peptide inhibits pancreatic exocrine secretion (Kohler et al., 1986), probably via specific receptors that have been found on acinar cells (Zhou et al., 1985), and its administration leads to inhibition of insulin release (Greely et al., 1985).

In the colon, too, CGRP-immunoreactive fibers have an extrinsic and presumably sensory nature, being derived from cells in the bilateral dorsal root ganglia-mainly at the S1 level but also at L1 and L6-some of which also contained substance P. The sensory component of the CGRP innervation of the colon consisted mainly of those fibers surrounding blood vessels, which, like those containing substance $\mathrm{P}$, disappeared after capsaicin 
Figure 9. A, Section from rat celiac ganglia showing True blue fluorescence after injection of the dye into the stomach. $B$, The same field viewed for fluorescein fluorescence showing cells immunostained for NPY. $\times 225$. Arrows indicate neuronal cell bodies retrogradely labeled with True blue and displaying NPY immunoreactivity. Same fixation and immunostaining as in Figure 7 .
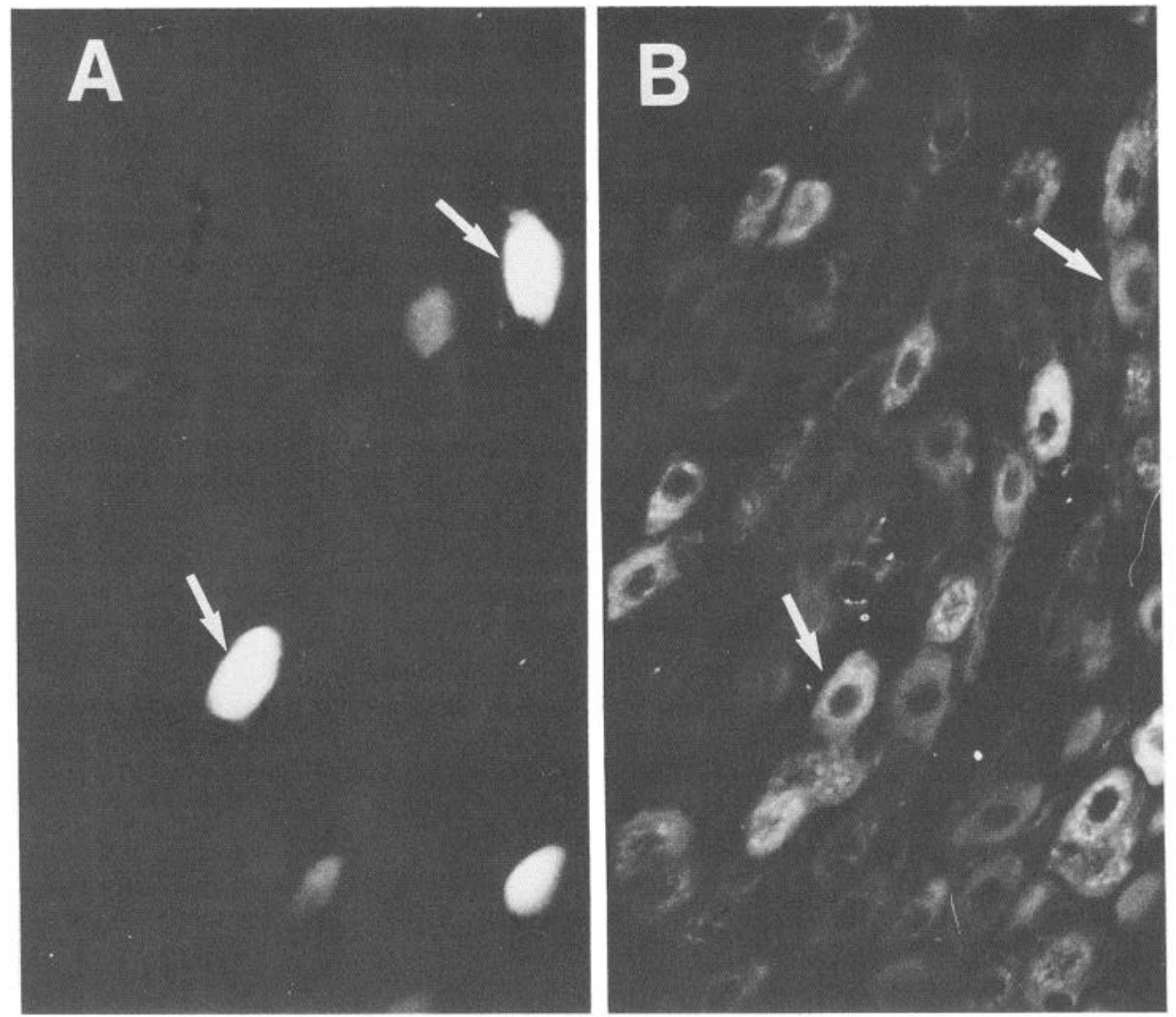

treatment. Thus, the CGRP innervation of the rat gut is not uniform. This differential distribution of CGRP nerves in the upper and lower gut suggests that they subserve different functions. Those of the upper gut appear to be mainly visceral afferents relaying nociceptive stimuli, while the large bowel receives a dual extrinsic and intrinsic supply. In the colon, the intrinsic CGRP-immunoreactive nerves may act as interneurons or as postganglionic parasympathetic neurons in control of motility (Feher et al., 1986; Maton et al., 1986). They could, for example, be afferents or inhibitory effectors in the myenteric reflex arc.

NPY-immunoreactive nerves in the gut and pancreas were found to have extrinsic and intrinsic origins, as has been suggested previously (Sundler et al., 1983; Ferri et al., 1984; Polak and Bloom, 1984; Carlei et al., 1985; Lee et al., 1985c). Treatment with 6-OHDA removed NPY-immunoreactive nerves from around blood vessels and reduced their number in the myenteric plexus. Upper abdominal sympathectomy and colon denervation had the same effect as 6-OHDA treatment, suggesting colocalization of extrinsic NPY with noradrenergic sympathetic nerves, as has been reported (Lundberg et al., 1982, 1983; Hökfelt et al., 1983; Ekblad et al., 1984c; Ferri et al., 1984; Polak and Bloom, 1984; Lee et al., 1985c; Allen and Bloom, 1986).

Retrograde tracing combined with immunocytochemistry provided further evidence that the extrinsic NPY nerves come from postganglionic sympathetic neurons. Recently, Lindh et al. (1986), using a combination of retrograde axonal tracing and indirect immunofluorescence, reported the projection of the postganglionic sympathetic neurons to the guinea pig pylorus; the majority of these cells were also immunoreactive to tyrosine hydroxylase. However, not all noradrenergic nerves in the gut and pancreas contain NPY, as only about half of True bluelabeled postganglionic sympathetic neurons contained NPY immunoreactivity. The intrinsic NPY-immunoreactive nerves are probably nonadrenergic (Sundler et al., 1983; Ekblad et al., 1984c; Ferri et al., 1984) and, in fact, an NPY immunoreactivity has been found in intramural neurons of the small intestine, which are also immunoreactive for VIP and peptide histidine isoleucine (PHI) (Ekblad et al., 1984a; Ferri et al., 1984). Therefore, NPY-immunoreactive nerve fibers in the gut and pancreas may have various subpopulations and play different roles in the regulation of gut (Emson and DeQuidt, 1984; Lundberg et al., 1984a; Hubel and Renquist, 1985; Allen and Bloom, 1986; Hellstrom, 1986) and pancreatic (Moltz and McDonald, 1985) functions.

A problem that can occur during retrograde tracing procedures is the diffusion of dye from the injected organ into the peritoneal cavity and surrounding vasculature. Uptake of this leakage by terminals in other abdominal viscera may cause inaccurate maps of ganglion labeling (Amy, 1980; Van der Krans and Hoogland, 1982). Recently, new methods for preventing such leakage have evolved; they include the use of gel foam (Lindh et al., 1986) or plastic wound spray (Fox and Powley, 1986), both of which act as diffusion barriers. In the present study, dye leakage was blocked by the careful isolation and washing of the injected organ and the application of plastic skin.

In conclusion, we have produced a detailed mapping of the origin of major types of peptide-containing nerves of the gut and pancreas of the rat, including the origins of 2 that have not been traced previously. Our results extend previous investigations on the nature of these nerves, providing further information on the anatomy of the enteric innervation. 


\section{References}

Allen, J. M., and S. R. Bloom (1986) Neuropeptide Y: A putative neurotransmitter. Neurochem. Int. 8: 1-8.

Amara, S. G., V. Jonas, and M. G. Rosenfeld (1982) Alternative RNA processing in calcitonin gene expression generates mRNAs encoding different polypeptide products. Nature 298: 240-244.

Amy, Y. (1980) Uptake sites of horseradish peroxidase after injection into peritoneal structures: Defining some pitfalls. J. Neurosci. Methods 2: 95-103.

Bishop, A. F., J. M. Polak, I. C. Green, M. G. Bryant, and S. R. Bloom (1980) The location of VIP in the pancreas of man and rat. Diabetologia 18: 73-78.

Bishop, A. E., G.-L. Ferri, L. Probert, S. R. Bloom, and J. M. Polak (1982) Peptidergic nerves. Scand. J. Gastroenterol. (Suppl. 71) 17: 43-59.

Bishop, A. E., J. M. Polak, Y. Yiangou, N. D. Christofides, and S. R. Bloom (1984) The distributions of PHI and VIP in porcine gut and their co-localisation to a proportion of intrinsic ganglion cells. Peptides 5: 255-259.

Bishop, A. E., J. M. Polak, F. E. Bauer, N. D. Christofides, F. Carlei, and S. R. Bloom (1986) The occurrence and distribution of a newly discovered regulatory peptide, galanin, in the human, porcine and rodent enteric nervous system. Gut 27: 849-857.

Brain, S. D., T. J. Williams, J. R. Tippins, H. R. Morris, and I. MacIntyre (1984) Calcitonin gene-related peptide is a potent vasodilator. Nature 313: 54-56.

Bryant, M. G., S. R. Bloom, J. M. Polak, R. H. Albuquerque, I. Modlin, and A. G. E. Pearse (1976) Possible dual role for vasoactive intestinal peptide as gastrointestinal hormone and neurotransmitter substance. Lancet 1: 991-993.

Carlei, F., J. M. Allen, A. E. Bishop, S. R. Bloom, and J. M. Polak (1985) Occurrence, distribution and nature of neuropeptide $Y$ in the rat pancreas. Experientia 41: 1554-1557.

Clague, J. R., C. Sternini, and N. C. Brecha (1985) Localization of calcitonin gene-related peptide-like immunoreactivity in neurons of the rat gastrointestinal tract. Neurosci. Lett. 56: 63-68.

Coons, A. H., E. H. Leduc, and J. M. Connolly (1955) Studies on antibody production. I. A method for the histochemical demonstration of specific antibody and its application to a study of the hyperimmune rabbit. J. Exp. Med. 102: 42-60.

Ekblad, E., R. Hakanson, and F. Sundler (1984a) VIP and PHI coexist with an NPY-like peptide in intramural neurones of the small intestine. Reg. Peptides 10: 47-55.

Ekblad, E., C. Wahlestedt, M. Ekelund, R. Hakanson, and F. Sundler (1984b) Neuropeptide $Y$ in the gut and pancreas. Distribution and possible vasomotor function. Front. Horm. Res. 12: 85-90.

Ekblad, E., L. Edvinson, C. Wahlestedt, R. Uddman, R. Hakanson, and F. Sundler (1984c) Neuropeptide Y co-exists and cooperates with noradrenaline in perivascular nerve fibres. Reg. Peptides 8: 225.

Ekblad, E., A. Rökaeus, R. Hakanson, and F. Sundler (1985) Galanin nerve fibers in the rat gut: Distribution, origin and projections. Neuroscience $16: 355-363$.

Emson, P. C., and M. E. DeQuidt (1984) NPY - a new member of the pancreatic polypeptide family. Trends Neurosci. $7: 31-35$.

Feher, E., G. Burnstock, I. M. Varndell, and J. M. Polak (1986) Calcitonin gene-related peptide-containing nerve fibres in the small intestine of the guinea pig: Electron microscopic immunocytochemistry. Cell Tissue Res. 245: 353-358.

Ferri, G.-L., A. Ali-Rachedi, K. Tatemoto, S. R. Bloom, and L. M. Polak (1984) Immunocytochemical localization of neuropeptide $\mathrm{Y}$-like immunoreactivity in extrinsic noradrenergic and intrinsic gut neurons. Front. Horm. Res. 12: 81-84.

Fischer, J., W. G. Forssman, T. Hökfelt, J. M. Lundberg, M. Reincke, F. A. Tschopp, and Z. Wiesenfeld-Hallin (1985) Immunoreactive calcitonin gene-related peptide and substance P: Co-existence in sensory neurones and behavioural interaction after intrathermal administration in the rat. J. Physiol. (Lond.) 362: 39P.

Fox, E. A., and T. L. Powley (1986) Tracer diffusion has exaggerated CNS maps of direct preganglionic innervation of pancreas. J. Autonom. Nerv. Syst. 15: 55-59.

Furness, J. B., and M. Costa (1980) Types of nerves in the enteric nervous system. Neuroscience $5: 1-20$.

Furness, J. B., R. E. Papka, N. G. Della, M. Costa, and R. L. Eskay
(1982) Substance P-like immunoreactivity in nerves associated with the vascular system in guinea pigs. Neuroscience $7: 447-459$.

Furness, J. B., M. Costa, P. C. Emson, R. Hakanson, E. Moghimzadeh, F. Sundler, I. L. Taylor, and R. E. Chance (1983) Distribution, pathways and reactions to drug treatment of nerves with neuropeptide $\mathrm{Y}$ - and pancreatic polypeptide-like immunoreactivity in the guineapig digestive tract. Cell Tissue Res. 234: 71-92.

Ghatei, M. A., S. K. George, J. H. Major, F. Carlei, J. M. Polak, and S. R. Bloom (1984) Bombesin-like immunoreactivity in the pancreas of man and other mammalian species. Experientia 40: 884886 .

Gibbins, I. L., J. B. Furness, M. Costa, I. MacIntyre, C. J. Hillyard, and S. Girgis (1985) Co-localization of calcitonin gene-related peptide-like immunoreactivity with substance $P$ in cutaneous, vascular and visceral sensory neurons of guinea pigs. Neurosci. Lett. 57:125130 .

Gibson, S. J., J. M. Polak, S. R. Bloom, I. M. Sabate, M. A. Mulderry, G. P. McGregor, J. E. N. Morrison, J. S. Kelly, R. M. Evans, and M. G. Rosenfeld (1984) Calcitonin gene-related peptide (CGRP) immunoreactivity in spinal cord of man and eight other species. J. Neurosci. 4: 3101-3111.

Greely, G. H., A. Alwmark, C. W. Cooper, and J. C. Thompson (1985) Calcitonin and calcitonin gene-related peptide inhibition of insulin secretion in vitro. Fed. Proc. 44: 1391.

Gulbenkian, S., A. Merighi, J. Wharton, I. M. Varndell, and J. M. Polak (1986) Ultrastructural evidence for the co-existence of calcitonin gene-related peptide (CGRP) and substance P (SP) in secretory vesicles of peripheral nerves in the guinea pig. J. Neurocytol. $15: 535-$ 542.

Hellstrom, P. M. (1986) Mechanisms involved in colonic vasoconstriction and in inhibition of motility induced by neuropeptide $Y$. Gastroenterology 90: 1456.

Hökfelt, T., J. M. Lundberg, K. Tatemoto, V. Mutt, L. Terenius, J. M. Polak, S. R. Bloom, C. Sasek, R. Elde, and M. Goldstein (1983) Neuropeptide Y (NPY)- and FRMF amide neuropeptide-like immunoreactivities in catecholamine neurons of the rat medulla oblongata. Acta Physiol. Scand. 117: 315-318.

Holmes, T. W. (1953) An evaluation of coeliac ganglionectomy in the prevention of experimental peptic ulcer. Ann. Surg. 138: 240-248.

Holzer, P., R. Gamse, and F. Lembeck (1980) Distribution of substance $P$ in the rat gastrointestinal tract-lack of effect of capsaicin treatment. Eur. J. Pharmacol. 61: 303-307.

Huang, W. M., S. J. Gibson, P. Facer, J. Gu, and J. M. Polak (1983) Improved section adhesion for immunocytochemistry using high molecular weight polymers of L-lysine as a slide coating. Histochemistry 77: 275-279.

Hubel, K. A., and K. S. Renquist (1985) Neuropeptide Y selectively increases chloride absorption. Gastroenterology 88: 1423.

Hughes, J. J., A. S. Levine, J. E. Morley, B. Z. Goskell, and S. E. Silvis (1984) Intraventricular calcitonin gene-related peptide inhibits gastric acid secretion. Peptides 5: 665-667.

Jessen, K. R., M. J. Saffrey, S. Van Noorden, S. R. Bloom, J. M. Polak, and G. Burnstock (1980) Immunohistochemical studies of the enteric nervous system in tissue culture and in situ: I ocalization of vasoactive intestinal polypeptide (VIP), substance $P$, and enkephalin immunoreactive nerves in the guinea-pig gut. Neuroscience 5: 17171735 .

Jodal, M., and O. Lundgren (1983) Nerves of the colon. In Colon: Structure and Function, L. Bustos-Fernandez, ed., pp. 187-209, Plenum, New York.

Kohler, E., J. Fischer, and K. Gyr (1986) Effect of human calcitonin gene-related peptide (CGRP) as exocrine pancreatic function. Gastroenterology 90: 1342.

Kraenzlin, M. E., J. L. C. Ch'ng, P. K. Mulderry, M. A. Ghatei, and S. R. Bloom (1985) Infusion of a novel peptide, calcitonin gene-related peptide (CGRP) in man. Pharmokinetics and effects on gastric acid secretion and on gastrointestinal hormones. Reg. Peptides 10:189197

Larsson, L.-I. (1979) Innervation of the pancreas by substance P, enkephalin, vasoactive intestinal polypeptide and gastrin/CCK immunoreactive nerves. J. Histochem. Cytochem. 27: 1283-1284.

Larsson, L.-I., J. Fahrenkrug, O. Schaffalitzky de Muckadell, F. Sundler, R. Hakanson, and J. F. Rehfeld (1976) Localization of vasoactive intestinal polypeptide (VIP) to central and peripheral neurons. Proc. Natl. Acad. Sci. USA 73: 3197-3200. 
Lee, Y., Y. Kawai, S. Shiosaka, K. Takami, H. Kiyama, C. J. Hillyard, S. Girgis, I. MacIntrye, P. C. Emson, and M. Tohyama (1985a) Coexistence of calcitonin gene-related peptide and substance P-like peptide in single cells of the trigeminal ganglion of the rat: Immunohistochemical analysis. Brain Res. 330: 194-196.

Lee, Y., Y. Takami, S. Girgis, C. J. Hillyard, I. MacIntyre, P. C. Emson, and $M$. Tohyama (1985b) Distribution of calcitonin gene-related peptide in the rat peripheral nervous system with reference to its coexistence with substance P. Neuroscience 15: 1227-1237.

Lee, Y., S. Shiosaka, P. C. Emson, K. F. Powell, A. D. Smith, and M. Tohyama (1985c) Neuropeptide Y-like immunoreactive structures in the rat stomach with special reference to the noradrenaline neuron system. Gastroenterology 89: 118-126.

Lindh, B., T. Hökfelt, L.-G. Elfvin, L. Terenius, J. Fahrenkrug, R. Elde, and M. Goldstein (1986) Topography of NPY-, somatostatin-, and VIP-immunoreactive, neuronal subpopulations in the guinea pig celiac-superior mesenteric ganglion and their projection to the pylorus. J. Neurosci. 6: 2371-2383.

Lundberg, J. M., T. Hökfelt, A. Anggard, K. Uvnäs-Wallensten, S. Brimijoin, E. Brodin, and J. Fahrenkrug (1980) Peripheral peptide neurons: Distribution, axonal transport and some aspects on possible function. In Neural Peptides and Neuronal Communications, E. Costa and M. Trabucchi, eds., Adv. Biochem. Psychopharmacol. 22: 2536.

Lundberg, J. M., L. Terenius, T. Hökfelt, C. R. Martling, K. Tatemoto, V. Mutt, J. Polak, S. R. Bloom, and M. Goldstein (1982) Neuropeptide Y (NPY)-like immunoreactivity in peripheral noradrenergic neurons and effects of NPY on sympathetic function. Acta Physiol. Scand. 116: 477-480.

Lundberg, J. M., L. Terenius, T. Hökfelt, and M. Goldstein (1983) High levels of neuropeptide $Y$ in peripheral noradrenergic neurons in various mammals including man. Neurosci. Lett. 42: 167-172.

Lundberg, J. M., L. Terenius, T. Hökfelt, and K. Tatemoto (1984a) Comparative immunohistochemical and biochemical analysis of pancreatic polypeptide-like peptides with special reference to the presence of neuropeptide $\mathrm{Y}$ in central and peripheral neurons. J. Neurosci. 4: $2376-2386$.

Lundberg, J. M.., X. Y. Huo, and A. Franco-Cereceda (1984b) Effects of neuropeptide Y (NPY) on mechanical activity and neurotransmission in the heart, vas deferens and urinary bladder of the guinea pig. Acta Physiol. Scand. 121: 325-332.

Maton, P. N., V. E. Sutliff, Z.-C. Zhou, J. D. Gardner, and R. T. Jensen (1986) Characterisation of receptors for calcitonin gene-related peptide (CGRP) a gastric smooth muscle cell. Gastroenterology 90: 1537.

Melander, T., T. Hökfelt, A. Rokaeus, J. Fahrenkrug, K. Tatemoto, and V. Mutt (1985) Distribution of galanin-like immunoreactivity in the gastro-intestinal tract of several mammalian species. Cell Tissue Res. 239: 253-270.

Minagawa, H., S. Shiosaka, H. Inoue, N. Hayashi, A. Kasahara, T. Kamata, M. Tohyama, and Y. Shiotani (1984) Origins and threedimensional distribution of substance P-containing structures on the rat stomach using whole-mount tissue. Gastroenterology 86: 51-59.

Moltz, J. H., and J. K. McDonald (1985) Neuropeptide Y: Direct and indirect action on insulin secretion in the rat. Peptides 6: 1155-1159.

Mulderry, P. K., M. A. Ghatei, A. E. Bishop, Y. S. Allen, J. M. Polak, and S. R. Bloom (1985) Distribution and chromatographic characterisation of CGRP-like immunoreactivity in the brain and gut of the rat. Reg. Peptides 12: 133-143.

Nilsson, G., L. I. Larsson, R. Hakanson, E. Brodin, B. Pernow, and F. Sundler (1975) Localisation of substance $P$ inmmunoreactivity in mouse gut. Histochemistry 43: 97-99.

Pearse, A. G. E., and J. M. Polak (1975) Immunocytochemical localization of substance $P$ in mammalian intestine. Histochemistry 41 : 373-375.

Polak, J. M., and S. R. Bloom (1979) Neuropeptides of the gut: A newly discovered major control system. World J. Surg. 3: 393-406.

Polak, J. M., and S. R. Bloom (1984) Regulatory peptides-the distribution of two newly discovered peptides: PHI and NPY. Peptides 5: 79-89.

Prinz, R. A., H. E. I. Sabbagh, T. E. Adrian, S. R. Bloom, I. Gardner, J. M. Polak, H. Inokuchi, A. E. Bishop, and R. B. Welbourn (1983) Neural regulation of pancreatic polypeptide release. Surgery 94: 10111018.

Rodrigo, J., J. M. Polak, L. Fernandez, M. A. Ghatei, P. Mulderry, and S. R. Bloom (1985) Calcitonin gene-related peptide immunoreactive sensory and motor nerves of the rat, cat and monkey oesophagus. Gastroenterology 88: 444-451.

Rosenfeld, M. G., J.-J. Mermod, S. G. Amara, L. W. Swanson, P. E. Sawchenko, J. Rivier, W. W. Vale, and R. M. Evans (1983) Production of a novel neuropeptide encoded by the calcitonin gene via tissue-specific RNA processing. Nature 304: 129-135.

Sawchenko, P. E., and L. W. Swanson (1981) A method for tracing biochemically defined pathways in the central nervous system using combined fluorescence retrograde transport and immunohistochemical techniques. Brain Res. 210: 31-51.

Schultzberg, M., T. Hökfelt, G. Nilsson, L. Terenius, J. F. Rehfeld, M. Brown, R. Elde, M. Goldstein, and S. Said (1980) Distribution of peptide-and catecholamine-containing neurons in the gastrointestinal tract of rat and guinea-pig: Immunohistochemical studies with antisera to substance $\mathrm{P}$, vasoactive intestinal polypeptide, enkephalins, somatostatin, gastrin/cholecystokinin, neurotensin and dopaminehydroxylase. Neuroscience 5: 689-744.

Sharkey, K. A., R. G. Williams, M. Schultzberg, and G. J. Dockray (1983) Sensory substance P-innervation of the urinary bladder. Possible site of action of capsaicin in rats. Neuroscience 10: 861-868.

Sharkey, K. A., R. G. Williams, and G. J. Dockray (1984) Sensory substance $P$ innervation of the stomach and pancreas. Demonstration of capsaicin-sensitive sensory neurons in the rat by combined immunohistochemistry and retrograde tracing. Gastroenterology 87:914 921.

Shay, H., S. A. Komarov, and M. Gruenstein (1949) Effects of vagotomy in the rat. Arch. Surg. 59: 210-226.

Sternberger, L. A., P. H. J. Hardy, K. K. Cuculis, and H. G. Meyer (1970) The unlabeled antibody-enzyme method of immunohistochemistry. Preparation and properties of soluble antigen-antibody complex (horseradish peroxidase-antihorseradish peroxidase) and its use in identification of spirochetes. J. Ilistochem. Cytochem. 18: 315333

Sternini, C., and N. Brecha (1986) Immunocytochemical identification of islet cells and nerve fibres containing calcitonin gene-related peptide-like immunoreactivity in the rat pancreas. Gastroenterology 90: 1155-1163.

Sternini, C., K. Anderson, and N. Brecha (1986) Colocalisation of calcitonin gene-related peptide immunoreactivity with substance $\mathrm{P}$ in the enteric nervous system of the guinea pig. Gastroenterology 90: 1648 .

Sundler, F., J. Alumets, J. Hakanson, J. Fahrenkrug, and O. Schaffalitzky de Muckadell (1978) Peptidergic (VIP) nerves in the pancreas. Histochemistry 55: 173-176.

Sundler, F., R. Hakanson, and S. Leander (1980) Peptidergic nervous systems in the gut. Clin. Gastroenterol. 9: 517-543.

Sundler, F., E. Moghimzadeh, R. Hakanson, M. Ekelund, and P. Emson (1983) Nerve fibers in the gut and pancreas of the rat displaying neuropeptide-Y immunoreactivity. Cell Tissue Res. 230: 487-493.

Tache, Y., M. Gunion, M. Lauffenburger, and Y. Goto (1984a) Inhibition of gastric acid secretion by intracerebral injection of calcitonin gene-related peptide in rats. Life Sci. 33: 871-878.

Tache, Y., T. Pappas, M. Lauffenburger, Y. Goto, J. H. Walsh, and H. Debas (1984b) Calcitonin gene-related peptide: Potent peripheral inhibitor of gastric acid secretion in rats and dogs. Gastroenterology 89: 344-349.

Takami, K., Y. Kawai, S. Shiosaka, Y. Lee, S. Girgis, C. J. Hillyard, I. MacIntyre, P. C. Emson, and M. Tohyama (1985) Immunohistochemical evidence of coexistence of calcitonin gene-related peptideand choline acetyltransfcrase-like immunorcactive ncurons of the rat hypoglossal, facial and ambiguous nuclei. Brain Res. 328: 386-389.

Tatemoto, K., M. Carlquist, and V. Mutt (1982) Neuropeptide Y-a novel brain peptide with structural similarities to peptide $Y Y$ and pancreatic polypeptide. Nature 296: 659-660.

Terenghi, G., J. M. Polak, M. A. Ghatei, P. K. Mulderry, J. M. Butter, W. G. Unger, and S. R. Bloom (1985) Distribution and origin of calcitonin gene-related peptide (CGRP) immunoreactivity in the sensory innervation of the mammalian eye. J. Comp. Neurol. 233: 506516.

Van der Krans, A., and P. V. Hoogland (1982) Labelling of neurons following intravenous injections of fluorescent tracers in mice. J. Neurosci. Methods 9: 95-103.

Wiesenfeld-Hallin, T., T. Hökfelt, J. M. Lundberg, W. G. Forssmann, M. Reinecke, P. Tschopp, and J. Fisher (1984) Immunorcactive calcitonin gene-related peptide and substance $\mathrm{P}$ coexist in sensory 
neurons to the spinal cord and interact in spinal behavioural responses of the rat. Neurosci. Lett. 52: 199-204.

Yiangou, Y., N. D. Christofides, M. A. Blank, N. Yanaihara, K. Tatemoto, A. E. Bishop, J. M. Polak, and S. R. Bloom (1985) Molecular forms of peptide histidine isoleucine-like immunoreactivity in the gastrointestinal tract. Gastroenterology 89: 516-524.

Zhou, Z.-C., M. Villaneuva, J. D. Gardner, and R. T. Jensen (1985)

Pancreatic acini possess a distinct receptor for calcitonin gene-related peptide (CGRP). Gastroenterology 88: 1643. 